\title{
Penelitian, Sebuah Proses Menemukan Makna
}

\author{
Ismail Suardi Wekke \\ *Pascsarjana Institut Agama Islam Negeri (IAIN) Sorong, Indonesia \\ **Necmettin Erbakan University, Turki \\ Email: iswekke@gmail.com
}

\begin{abstract}
Abstrak
Artikel ini merupakan bahan ajar dalam perkuliahan di pascasarjana IAIN Sorong. Untuk memberikan pengayaan dan juga pengantar belajar bagi mahasiswa. Sekaligus sebuah materi belajar untuk menjadi bahan belajar bersama. Belajar dalam mata kuliah Metode Penelitian dengan menumpukan pada tema pendidikan agama Islam. Bahkan secara khusus lagi, kepemimpinan transformatif.
\end{abstract}

Kata kunci: artikel, kemahiran, kemampuan, keterampilan

\section{Pendahuluan}

Saudara-saudari...

Materi perkuliahan kita sudah selesai. Ini dari sisi waktu saja. Namun, jika masih berkenan, saya akan terus mengirimkan informasi yang terkait dengan penelitian.

Kemampuan meneliti sejatinya adalah kemampuan "belajar". Dimana tidak dapat diselesaikan dengan sekali duduk dalam mata kuliah saja.

Apalagi penelitian menjadi sebuah cara. Tak lain hanyalah metode. Hanya dengan metode yang tepat itu, kemudian bisa menjadikan penemuan sebuah informasi yang pada akhirnya dapat disebut sebagai ilmu pengetahuan.

Saya sejenak hanya mau cerita. Ketikan ini saya selesaikan dalam badan sebuah pesawat. Terbang dari Abu Dhabi ke Istanbul. Pesawat dengan produksi Boeing yang diberi merek Dreamliner. Dioperasikan oleh Ettihad.

Mari kita lihat, pesawatnya dibuat oleh perusahaan yang sama. Hanya saja, selera yang memesannya berbeda-beda. Maka, walaupun sama-sama Boeing tetapi dipesan oleh perusahaan berbeda tetap saja berbeda. Walau sejatinya semuanya tetap sama, dari bahan yang sama. Tangan yang sama, bahkan perusahaan yang sama.

Ketika diserahkan ke Ettihad. Dioperasikan dengan manajemen yang berbeda. Apakah sama ketika dioperasikan oleh Garuda? Berbeda. Tidak sama lagi. Sejak awal sudah ada perbedaan tadi. Selera, pemesan pesawatnya.

Pesawat berbeda perlakuan dengan mobil. Mereka Toyota, dengan kategori Inova, tetap sama. Ketika dibeli oleh siapapun.

Saya mengantar cerita ini sebagai bagian dari kuliah kita. Sama, akan pada saatnya nanti. Anda melihat fenomena yang sama, tetapi dengan "selera" berbeda tadi. Maka, akan sama sekali berbeda dengan apa yang dihasilkan dalam bentuk publikasi. 
Apa yang perlu kita pelajari dari sini? Bahwa dengan metode penelitian, kita harus belajar Bersama bagaimana bisa mendapatkan "wahyu". Saya menyebutnya wahyu dengan asosiasi bahwa kemahiran meneliti sepenuhnya adalah pammase (pemberian Allah).

Dengannya, kita tetap perlu mendekatkan kepada Allah dalam belajar. Bahasa yang digunakan Imam Syafii bahwa ilmu itu nur. Merupakan cahaya Allah, maka hanya diberikan kepada orang yang terpilih.

Tetap perlu belajar, tetap perlu membaca, tetap perlu diskusi. Bersamaan dengan itu semua, mendekatkan diri kepada Allah sebagai bagian dari penghambaan di jalan-Nya juga tidak boleh terpisahkan.

Saya ingin menutup kuliah kita dengan mengingatkan diri saya sendiri. Jikalau saja, dalam proses mengingatkan diri saya sendiri ini juga ada yang bisa dibagi kepada kita semua, tentu akan sangat baik sehingga menjadi pelajaran dan pembelajaran.

Sedikit saja terkait dengan materi pelajaran kita bahwa meneliti harus sistematis (Wekke, 2021). Ide dapat juga dikembangkan dari dua topik, sehingga bisa digabungkan (Wekke, Umbar, \& Arsyad, 2016; Wekke \& Busri, 2016).

Memungkinkan pula apa yang menjadi sebuah praktik (Wekke \& Faisol, 2016; Wekke, 2019; Nuryantika, Amin, \& Wekke, 2021; Wekke, 2015). Sekecil apapun itu, sepanjang merupakan fenomena (Lestari, Amin, \& Wekke, 2021).

Bahkan apa yang dilihat sehari-hari, dapat dijadikan sebagai sebuah penelitian. Bisa didekati dengan sebuah informasi yang trend. Atau sementara didiskusikan (Wekke \& Nur, 2016). Kalau ini belum dapat dilihat secara lengkap dan komprehensif, memungkinkan untuk dipublikasikan dengan temuan awal (Wekke \& Muttaqien, 2016).

Oleh itu, bolehjadi penelitian adalah serba kemungkinan.

\section{Apa yang Akan Ditulis?}

Target pertama tujuan artikel:

https://jiran.unaim-wamena.ac.id/index.php/jiran/index

Boleh jadi adalah review. Hanya saja, walaupun merupakan review tetap saja ada sebuah "novelty" yang perlu dikemukakan.

Kata "novelty" inilah yang sejak awal harus dijadikan sebagai tolok ukur, bukan tolak ukur ya.

\section{Penutup}

Sebagaimana uraian saya terkait dengan kemampuan mahasiswa pascasarjana dalam bahan belajar sebelumnya. Ini merupakan keperluan, kalau saya tak menyebutnya kewajiban. Jangan sampai menjadi sebuah beban.

Saya kemudian gembira mendengarkan cerita dari alumni pascasarjana IAIN Sorong yang kini menempuh Pendidikan di UIN Sunan Kalijaga, dimana latihan yang dilaksanakan di kelas-kelas yang saya ampuh kemudian berguna dalam perjalanan studi mereka. 


\section{Daftar Pustaka}

Nuryantika, N., Amin, S., \& Wekke, I. S. (2021). Strategi Penerapan Akhlak Islami "Sadar Sampah" Di Sekolah Islam Terpadu. Penerbit Adab.

Wekke, I. S. (2015). Arabian society in Kaili lands, central Sulawesi: Arabic education and its movement. Tawarikh, 7(1).

Wekke, I. S. (2019). Pendidikan dan Kesempatan Memperoleh Akses Belajar: Perguruan Tinggi Islam di Papua. Simposium Pendidikan Teknologi, Industri, dan Pendidikan, Surakarta, 16 Februari 2019. Surakarta: Majelis Nasional Korp Alumni Himpunan Mahasiswa Islam (KAHMI).

Wekke, I. S. (2021). Metode Penelitian Pendidikan Agama Islam Kepemimpinan Transformatif. Yogyakarta: Bintang Pustaka Madani.

Wekke, I. S., \& Busri, M. (2016). Kepemimpinan Transformatif Pendidikan Islam: Gontor, Kemodernan, dan Pembelajaran Bahasa. Deepublish.

Wekke, I. S., \& Faisol, F. (2016). Aplikasi Dan Prinsip Belajar Dalam Pembelajaran Bahasa Arab Perguruan Tinggi Minoritas Muslim. Prosiding Konferensi Nasional Bahasa Arab, 1(2).

Wekke, I. S., \& Muttaqien, A. (2016). Kajian Awal Realitas Dan Praktik Pembelajaran Bahasa Arab Madrasah Minoritas Muslim Papua Barat. Prosiding Konferensi Nasional Bahasa Arab, 1(2).

Wekke, I. S., \& Nur, M. (2016). Belajar dan Pembelajaran Bahasa Arab Madrasah Minoritas Muslim Papua Barat. Prosiding Konferensi Nasional Bahasa Arab, 1(2).

Wekke, I. S., Umbar, K., \& Arsyad, A. (2016). Tradisionalisme dan Modernisme Pembelajaran Bahasa Arab: Pembelajaran Madrasah Berbasis Pesantren Minoritas Muslim. Prosiding Konferensi Nasional Bahasa Arab, 1(2). 